\title{
Diego Rivera and the Left: The Destruction and Recreation of the Rockefeller Center Mural
}

\section{Dora Apel}

Diego Rivera, widely known for his murals at the Detroit Institute of Arts and the San Francisco Stock Exchange Luncheon Club, became famous nationally and internationally when his mural for the Radio City of America (RCA) Building at Rockefeller Center in New York City was halted on 9 May 1933, and subsequently destroyed on 10 February 1934 . Commissioned at the height of the Depression and on the eve of Hitler's rise to power, Rivera's mural may be read as a response to the world's political and social crises, posing the alternatives for humanity as socialist harmony, represented by Lenin and scenes of celebration from the Soviet state, or capitalist barbarism, depicted through scenes of unemployment, war and "bourgeois decadence" in the form of drinking and gambling, though each side contained ambiguous elements. At the center stood contemporary man, the controller of nature and industrial power, whose choice lay between these two fates. The portrait of Lenin became the locus of the controversy at a moment when Rivera was disaffected with the policies of Stalin, and the Communist Party (CP) opposition was divided between Leon Trotsky and the international Left Opposition on one side, and the American Right Opposition led by Jay Lovestone on the other. In his mural, Rivera presented Lenin as the only historical figure who could clearly symbolize revolutionary political leadership. When he refused to remove the portrait of Lenin and substitute an anonymous face, as Nelson Rockefeller insisted, the painter was summarily dismissed, paid off, and the unfinished mural temporarily covered up, sparking a nationwide furor in both the left and capitalist press. While the art historical literature has largely dealt with the events surrounding the RCA mural in terms of Rivera's relationship to his capitalist patrons, this article considers the political motivations for Rivera's artistic practice in terms of his relationship to the Communist left, a key sector of his audience.'

The same year the project was terminated, Rivera took its most controversial motif and expanded it to include the portraits of a dozen revolutionary leaders in a unified stand. This was the culminating panel of a series of twenty-one murals portraying a radical history of America at the New Workers School in New York, run by the Lovestone group. ${ }^{2}$ In a show of nonsectarianism, Rivera then painted two small panels, now lost, at the Trotskyist headquarters in New York, featuring Trotsky's leading role in the Russian Revolution and the incipient Fourth International. ${ }^{3}$ 
When the RCA mural was destroyed in 1934, Rivera was granted permission by the Mexican government to recreate it in the Palace of Fine Arts in Mexico City, and added several portraits, including that of John D. Rockefeller Jr. to the capitalist side, and Trotsky, Marx, Engels, Lovestone and Bertram Wolfe, with the banner of the Fourth International, to the socialist side, altering the meaning of the original mural. Produced in the context of Stalin's failure to mobilize against the rise of fascism in Germany and Trotsky's call for an unstained banner, it represents an open rejection of the official Soviet party. Rivera's artistic practice, then, is closely bound up with his evolving political stance in relation to the $\mathrm{CP}$ and its most important opposition group, the Trotskyists.

The painter's biographer, Bertram Wolfe, however, attempts to bury the history of Rivera's relationship to Trotskyist politics and ideas in the late twenties and early thirties, though paralleling both the painter's own later revisionist view of his past, as well as the attempts of bourgeois agencies to whitewash Rivera's radical past. Wolfe portrays Rivera as a political clown whose Trotskyist politics were taken seriously by no one, least of all by Rivera himself. Wolfe was a member of the Lovestone group and director of the New Workers School, where he helped Rivera plan the mural series on America and subsequently wrote the text for the mural illustrations published as Portrait of America. But Wolfe's early critique of Stalinism had grown into outright antiCommunism by the time he published The Fabulous Life of Diego Rivera in 1963, where he characterizes Rivera's most "proletarian" and internationalist work as so much lifeless propaganda in comparison to the more populist Mexican murals which explore the roots of Mexican culture. ${ }^{4}$ Relying on Rivera's well-known tendencies to invent and exaggerate, Wolfe casts doubt on the significance of Rivera's political activity outside of Mexico as a means of distancing him from the political implications of works that deal with themes other than Mexican populism. By creating two men out of Rivera, one who was artistically committed and one who was politically unserious, Wolfe sought to absolve Rivera of the political responsibility for either his work or his actions in order to canonize him as a great artist. ${ }^{5}$

Later historians, using Wolfe's account as the basis for Rivera's life, have portrayed Rivera as a mighty artistic technician and complex iconographer whose U.S. murals in general, because of their "propagandistic" content, have been regarded as inferior to his more nativist and populist works in Mexico. ${ }^{6}$ The relationship between Rivera's artistic practice and the Communist Party has been superficially examined by art historians, as has his relationship with the Lovestone group and Trotskyist politics. Max Kozloff was the first historian to 
rescue Rivera's U.S. murals, in particular the Detroit Industry murals, from their neglect by art historians, and to favorably compare them with the Mexican murals in his seminal study of proletarian art under capitalist patronage. ${ }^{7}$ The 1986 exhibition catalog on the Rivera retrospective at the Detroit Institute of Arts contains two essays which usefully discuss the theoretical influence of Marxism but, like Kozloff's article, they do not discuss Rivera's specific relationship to Stalinism or Trotskyism. ${ }^{8}$ In the most thorough examinations of Rivera's Rockefeller Center mural and its recreation in Mexico City, such as Laurance Hurlburt's Mexican Muralists in the United States and Irene Herner de Larrea's Diego Rivera's Mural at Rockefeller Center, Hurlburt fails to mention the inclusion of Trotsky and the banner of the Fourth International in the recreated mural and excludes it from the illustration in his book, while Herner de Larrea provides description without interpretive comment. ${ }^{9}$

In his own writings, Rivera supported Trotskyist criticism of the Stalinists in the early thirties; in the later thirties he formally joined the Trotskyists and signed a call for the freedom of art with André Breton, co-written by Breton and Trotsky; ${ }^{10}$ he also wrote for the press of the Fourth International. ${ }^{11}$ Ultimately, however, the painter himself attempted to obscure his relationship to Trotskyism when he applied for readmittance to the Communist Party in the $1940 \mathrm{~s},{ }^{12}$ and strove to distance himself as much as possible from Stalinism's greatest enemy on the left with which he had been associated for ten years. ${ }^{13}$

In the 1930s, Rivera was primarily concerned, not with the programmatic demands of his bourgeois patrons, though he struggled to survive as a socialist artist in a capitalist society, but with negotiating a position as an autonomous artist within the political arena on the left. Rivera's efforts to assert his political integrity and simultaneously maintain artistic independence had the greatest impact on the iconography of his RCA mural, culminating in the recreated mural in Mexico City. Why was Rivera drawn to Trotskyism and away from the larger Communist Party? What was the process by which the changes between the RCA mural in New York and its recreation in Mexico City over a year later were brought about?

\section{ROCKEFELLER CENTER}

A closer look at the RCA mural reveals a richly interconnected multi-space, multi-time composition drawing together all levels of human knowledge and existence - nature, science, industry, social and political life - based on axial dualities. Rivera contrasts the physical properties of the microcosm and macrocosm while commenting on the political duality of capitalism and socialism. The central figure shows man as a skilled worker in control of the 
macrocosm and microcosm and generating a new human society. In all, three walls of the ground floor elevator bank in the RCA Building were part of the mural painted by Rivera. The left wall portrayed human intelligence in possession of the forces of nature; the right wall showed the workers in control of society after the overthrow of tyrannical rule. A statue of Caesar with a swastika engraved on it was portrayed with its head cut off. The main wall contrasted chemical warfare on the upper left with scenes of a Communist May Day celebration on the upper right. Below the May Day scene were female track hurdlers, and opposite them, an unemployment demonstration in the Wall Street area. In the center, a large cylinder at the top represented a telescope and a smaller cylinder below it a microscope, with their two visual fields represented as ellipses and crossed in the center. These spheres revealed biological and cosmic symbols that referred to capitalist and socialist society. On the capitalist side, a scene of drinking, card-playing and dancing in a nightclub, depicting Rivera's idea of bourgeois decay and corruption, was placed above the moon, a dead planet, and the soiled earth. Above the nightclub, reinforcing the idea of decadence, were the microbes of disease resulting from debilitating life under capitalism. On the socialist side, the ellipse representing the vision of the telescope portrayed constellations and nebulae in ascending evolution, highlighted by the glowing red star of Mars, which contained a hidden hammer and sickle. ${ }^{14}$ The lower segment, oddly, began with cancer cells, symbolizing the state of Stalin's leadership in the Soviet Union, ${ }^{15}$ and continued with images concerning the generation of human life. In front of the central figure was a crystal sphere representing the splitting of the atom. At the far sides of the ellipses, two large magnifying glasses revealed the realities of the capitalist and socialist worlds to the spectators. ${ }^{16}$

Between the two segments of the ellipses on the right, opposite the frivolity of the nightclub scene, Rivera presents Lenin joining together the hands of a soldier and two workers, black and white. The choice of Lenin as the revolutionary leader is in part explained by the implicit critique of Stalin contained in the mural. Lucienne Bloch, an artist and assistant to Rivera, maintains that Rivera introduced the portrait of Lenin as the symbol of true Communism instead of Stalin, whom he viewed as a false and dangerous representative of Communism. ${ }^{17}$ Lenin's presence thus makes more conspicuous the absence of Stalin, who was the contemporary head of the Soviet state, and presents Lenin as a model undisputed on the left. Another of Rivera's assistants on the mural, Ben Shahn, suggests that Rivera craved positive criticism from his former comrades of the Communist Party and its U.S. organs The Daily Worker and The New Masses, which had harshly criticized him up to 
that point, charging him with co-optation by the forces of capitalism as "the painter for millionaires." ${ }^{18}$ Robert Evans (pseudonym for Joseph Freeman), for example, in an article in The New Masses, charged that Rivera's expulsion from the Communist Party in 1929, caused him to be "automatically cut off from the masses whose life and aspirations furnished him not only with the themes of his murals but with that faith and purpose which are indispensable to great art."19 Such attacks stung Rivera and goaded him into asserting his political integrity in spite of the effect it might have on his bourgeois employers, while at the same time asserting his independence from the Communist Party. In the WorldTelegram article which launched the public controversy over the mural, Rivera is quoted as saying, as though in angry reply to the New Masses, "I am painting for my class - the working class. ... But I am not one prostitute with the workers. I am not one bourgeois worker, or bourgeois painter, or bourgeois thinker. I am one man who works for my own interests, and my interests are the interests of my class." ${ }^{20}$ Ten days after the World-Telegram article appeared, Nelson Rockefeller requested in a letter the removal of Lenin's portrait. ${ }^{21}$ Rivera's assistants threatened to strike if he complied with the request and Rivera replied with a letter refusing to remove Lenin's portrait but offering to substitute a portrait of Lincoln and other American leaders for the nightclub scene as a compromise. Lucienne Bloch claims that Rivera desperately wanted to finish the mural and prove his political integrity both to his patrons and to his Communist Party detractors. ${ }^{22}$ But Rivera was stopped from further painting on 9 May, even before receiving a final letter terminating the project that same evening.

Rivera's assistants mobilized a protest campaign and within two hours more than a hundred protesters gathered outside the RCA building with placards and signs. ${ }^{23}$ Both the Trotskyists and Lovestoneites participated in the demonstration, but the Communist Party abstained, caught in an ideological bind between the Rockefeller capitalists and the "opportunist" Rivera, who was nonetheless branded a Communist. Rivera's defenders organized a united-front defense committee the next day, chaired by Ben Shahn, as the news made frontpage headlines. Representatives from the Left Opposition, I.W.W., Right Opposition, other socialist and anarchist groups, and Communist Party groups such as the John Reed Club and Workers School, were present. The John Reed Club attempted to sabotage the committee by putting forward a long resolution in effect condemning Rivera for a whole series of past acts. ${ }^{24}$ Pressured by their own membership to take part in the official protest, the Communist Party representatives ultimately agreed to be bound by the purposes of the united front, though their spokesmen at a mass meeting declared that no revolutionary work could be done except under the leadership of the Communist Party. The 
Lovestoneites defended Rivera as a revolutionary artist in their press, Workers Age, noting that the Communist Party refused to participate in the demonstration at the RCA Building. ${ }^{25}$ The following month Rivera defended his unfinished mural and presented his views on art in a supplement for Workers Age.

The Daily Worker defended the mural against Rockefeller's attack, but described Rivera as an artist whose morale had been broken, making him "Morgan's artist, Rockefeller's artist, Ford's artist where once he had been the Mexican workers' and peasants' artist." ${ }^{26}$ The New Masses, more circumspect, also defended Rivera against Rockefeller's attack, being careful to note, however, "We do not wish to discuss here Rivera as a political figure. With his political line we are not in agreement. We have differences with him on many important questions." 27 These differences referred to Rivera's political sympathies with the Trotskyists. The Trotskyists also defended Rivera in their press, the Militant, without caveat. They interpreted the preparation for the destruction of the mural by the Rockefeller interests as an act of vandalism comparable to the book burnings of Hitler in the public squares of Germany. The attacks of the Communist Party were implicitly countered by upholding Rivera's credentials as a revolutionary artist who, since he was not financially independent, naturally accepted assignments from bourgeois patrons. ${ }^{28}$ The Trotskyists called for a workers' defense of revolutionary art and were the first to organize, under the auspices of their own International Workers School, a benefit program and platform for Rivera to speak at Town Hall on 13 May. During the defense campaign, the Militant noted with approval "the active and often leading role of the Left Opposition, with which Rivera openly showed his political sympathy."29

\section{RUSSIA AND THE MEXICAN COMMUNIST PARTY}

How was this radical political vision by Rivera arrived at in 1933? In order to answer this question, we must look at Rivera's relationship to Soviet politics and art in the preceding two decades. During his years in Paris in the second decade of the century, he affiliated with a group of Russian artists, writers and collectors who kept in touch with the political and artistic developments in Moscow. Rivera's friend David Sternberg later became Soviet People's Commissar of the Fine Arts and invited him to Russia. ${ }^{30}$ Rivera joined the Mexican CP in 1922, a year after his return from Paris, and formed the Union of Technical Workers, Painters, and Sculptors with David Alfaro Siqueiros, Xavier Guerrero, and others, and with the support of Jose Clemente Orozco. Their manifesto proclaimed, in part, "We repudiate the so-called easel painting and all 
the art of ultra-intellectual circles, because it is aristocratic and we glorify the expression of Monumental Art [mural art] because it is a public possession." ${ }^{31} \mathrm{El}$ Machete, the newspaper of the Painters' Union, became the journal of the Mexican CP with Rivera, Siqueiros and Guerrero as its editors. Thus the ideas of artists in revolutionary Russia, in conjunction with ideas aroused by the Mexican Revolution, helped to establish a credo of anti-elitist and public art in the Mexican mural movement.

Rivera was elected to the CP Central Committee in 1925, along with Bertram Wolfe, who was then living and working in Mexico. Wolfe describes Rivera's services and contributions to the Mexican CP from 1926 to 1929 as bringing it prestige, carrying on polemics on its behalf in the press, and using his influence as a mural painter with the government to shield CP members from persecution or to get them out of jail. Rivera drafted many documents, including the declarations of the Anti-Imperialist League and the National Peasant League, the statutes and program of the Workers and Peasants Bloc, and manifestos to be posted on walls. He also became head of the Mexican CP delegation to Moscow, a delegate of the Mexican Peasant League, General Secretary of the Anti-Imperialist League and editor of its official organ El Libertador. Finally, Rivera managed the CP presidential campaign of 1928-29 and was the Mexican correspondent for Barbusse's newspaper Monde. ${ }^{32}$ Rivera, then, was not only fully engaged by Mexican Communist politics but was one of its leading exponents both organizationally and in print, recognized and acknowledged as a party spokesman.

The painter made his first trip to the Soviet Union in September 1927, as part of the Mexican delegation in honor of the tenth anniversary celebration of the Russian Revolution, and remained in Moscow until June 1928. It was during this period that Rivera first became aware of the Trotskyist criticism of the Stalinist program. ${ }^{33} \mathrm{He}$ also became a founding member of the Russian artist group October in 1928, along with other prominent Russian artists such as El Lissitzky, Sergei Eisenstein, and Alexander Rodchenko. October emphasized a non-elitist public art which served the proletariat. Its goal was to raise the cultural level of the working class which would build the Soviet economy and culture on the basis of organized planning and a highly developed industrial technology. The issue of artistic freedom was addressed in the group's founding manifesto which called for the wholly unrestricted competition of various tendencies and schools of art and rejected the ideological monopoly of any single group in representing the interests of the Soviet population. The declaration emphatically criticized Soviet cultural policy as it was beginning to be practiced: "We reject the system that can allow an artificially created and 


\section{Left History 6.1}

privileged position (moral and material) for any one artistic group at the expense of other associations or groups; this is a radical contradiction of the Party's and the government's artistic policy." ${ }^{34}$

On 24 November 1927, Rivera signed a contract with Lunacharsky, Commissar of Education and Fine Arts, to do a fresco in the Red Army Club, but came under fire from academics who criticized him for his attack on easel painting, and for encouraging the use of peasant art and the popular tradition of Russian folk art. His requests for material and assistants for the commissioned mural were repeatedly delayed, until the Latin American Secretariat of the Comintern reported that the Mexican Communist Party had ordered Rivera home on the pretext that he was needed to manage their presidential campaign. Rivera was apparently glad to go and left suddenly without finishing the mural or saying good-bye to his artist friends. ${ }^{35}$ The underlying reasons for Rivera's sudden friction with the Stalin regime appear to be deeper than questions of artistic differences and are related to Rivera's sympathy for the Trotskyist faction of the Soviet party, which criticized and sought to reform the program of the Stalinized CP. ${ }^{36}$ Trotsky counterposed international revolution to the Stalinist conception of "socialism in one country" and advocated the concept of "permanent revolution," in which the bourgeois revolution in the modern period would need to "grow over" into social revolution led by the working class, as against the Stalinist notion of a "two-stage" revolution in which the proletariat would subordinate itself to the bourgeoisie in the "first stage" and allow it to take state power. ${ }^{37}$ According to Siqueiros, Rivera first manifested support of Trotsky's faction within the Soviet CP when he sided with the Catalan Communist Andrès Nin's call for support of Trotsky's ideas at the 4th Congress

of the Red International Syndicate, held in Moscow in 1928, to which Siqueiros went as the delegate of the Jalisco miners' union. ${ }^{38}$

In an article on the position of artists in Russia, written in 1932, Rivera commented on the bureaucratic degeneration of the Stalinist leadership, which formed part of the programmatic basis of the Left Opposition to which he alludes:

This is one of the varied results of the actual descending curve (transitory degeneration) of the Russian bureaucratized Communist Party, against which the sane revolutionary forces of the entire world are struggling, an opposition which the international functionaries, petty leaders, and the intellectual lackeys of Sir Joseph Stalin reward with the titles of renegades, traitors, and social fascists. But these gentlemen will have, against the true revolutionary ideology and the 
true art of the revolution, the same efficacy as a drunkard who, having stolen a pair of scissors, tries to cut with it a ray of light. ${ }^{39}$

Rivera eventually joined the Left Opposition in the summer of 1936, and in November interceded with President Lázaro Cárdenas to grant Trotsky political asylum. After successfully helping to bring the old revolutionary to Mexico at the beginning of 1937, a congenial relationship ensued between the two men until Trotsky broke with Rivera in 1939 over political differences. ${ }^{40}$

\section{EXPULSION FROM THE COMMUNIST PARTY}

In 1929 Rivera was expelled from the Mexican Communist Party. Proffered reasons vary, largely centering on charges of artistic "opportunism" in accepting commissions from the government. Being pressed to choose between artistic survival and Party membership may have been sufficient to create a rift between Rivera and the $\mathrm{CP}$, but once again, there seem to be underlying political reasons related to Rivera's sympathies for the Trotskyist opposition. Although Wolfe claims that Rivera did not become an adherent of Trotsky until after his expulsion, and that the charge did not figure at all in his trial and defense, ${ }^{41}$ Siqueiros accused Rivera of "deliberately engineering" his own expulsion from the Party "by claiming to be more radical than the Party, that is to say, a Trotzkyite."42

Wolfe's explanation is that the expulsion was the result of an international purge of the "Right Danger" in which Rivera was scapegoated on specious charges. But Wolfe himself notes that Rivera "was prepared by his experience with Soviet art to accept the emphasis that Trotsky placed on Russian bureaucracy" as the cause of Soviet political degeneration. Wolfe further suggests that the figure of Trotsky would have appealed to Rivera, not only as the heroic leader of the Red Army, but because of his own fate in being expelled from the Party and exiled, and because he was more sensitive to art and literature and more tolerant of innovation than any other outstanding leader of the October Revolution, except for Lunacharsky and Bukharin. ${ }^{43}$ But beyond any romantic attraction to the figure of Trotsky that may have existed, Rivera appears to have had differences with the Comintern and the Mexican CP on specific political grounds. He opposed the 1929 policy of Red or dual trade unions, which called for the withdrawal of militant workers from already established trade unions and the formation of separate Communist unions. Both the Trotskyists and the Lovestoneites also disagreed with the policy of dual trade unions. Rivera further opposed the decision of the Mexican CP to sever its links with left-leaning elements of the Mexican government and to call for a workers' and peasants' 
uprising during the 1928-29 election campaign ${ }^{44}$ Rivera issued a statement to the press ascribing his expulsion to his Trotskyism and criticizing the Soviet bureaucracy. ${ }^{45}$ There may well have been an element of advantage in this inasmuch as the difficulty for Rivera then became maintaining a position of political integrity as a leftist that would neither involve an attack on his former comrades, who were already in a precarious position with the government, nor undermine his government patronage, without which he could not have continued to paint. The CP continued its criticism of Rivera for his support of José Vasconcelos, the government minister who sponsored the mural renaissance and Rivera in particular, and for accepting a mural commission from Dwight Morrow, the American ambassador to Mexico who was seen as the representative of imperialism. ${ }^{46}$ But Rivera was not the only one who found himself in the position of having to choose between artistic and political practice in this period: Siqueiros gave up painting for full-time politics, Orozco went to New York disgusted with Mexican politics, and Guerrero gave up art and went to Moscow.

\section{ROCKEFELLER, RIVERA, AND THE LEFT}

Rivera's expulsion from the Mexican Communist Party facilitated the marketing of Rivera to American bourgeois patrons. The New York Times Magazine ran a feature article praising Rivera's work and reassuringly noting that he was no longer a Communist but a nativist painter at heart. ${ }^{47}$ Francis Flynne Paine, an American dealer of Mexican arts, became the liaison between Rivera and the Rockefellers and helped organize a successful one-man retrospective for Rivera at the Museum of Modern Art in 1931. Flynn also wrote the introduction to the exhibition catalog in which she discussed Rivera's conflict between the Communist Party and painting, explaining that he was expelled for liking to paint and concluding: "Diego's very spinal column is painting, not politics." 48

Yet for Rivera, the two were inseparable: "On one front is a struggle against the production of bourgeois art - and when I say struggle I mean struggle in every sense - and on the other is a struggle to develop the ability of the proletariat to produce its own art."49 Rivera saw himself as a worker, and believed mural art was the most significant art for the proletariat. In spite of the Stalinists' belief that revolutionary work could only occur under their leadership, Rivera believed that if a painter "succeeds in painting art for the proletariat, the proletariat will understand it ... will defend his art, proletarian art." ${ }^{50}$ His position on proletarian art as an art by and for the worker, which could be produced even under capitalism, was far closer to the view of the Stalinists 
and leftist artists affiliated with the John Reed Clubs in the early thirties than to Trotsky's views. Trotsky believed that true proletarian art would be produced only as a "classless" art in a classless society. ${ }^{51}$ This helps explain why Rivera was sensitive to the Stalinists' recognition and approval of his work, and his adoption of the slogan "Art is a Weapon in the Class Struggle," coined by American Communist Robert Minor in 1925. The Communist Party nevertheless refused to grant Rivera's revolutionary artistic credentials as long as he was outside of their movement, attacking him not only in their press, but at a John Reed Club meeting at which he was invited to speak. ${ }^{52}$ The Trotskyists, on the other hand, formally took a negative position on artistic policy, calling for artistic freedom and independence. In this sense, Rivera's refusal to be dictated to by the Party, and his view that the work of a revolutionary artist was automatically revolutionary, was closer to the Trotskyists. As the profound social crisis in Germany revealed the inability of the Stalinists to mobilize a fight against fascism, Rivera also grew more distant from them politically. Trotsky called for united opposition to the forces of fascism by all working class organizations, while the Stalinists characterized the Social Democratic workers' organizations as "social fascist" and divided the opposition against Hitler, allowing him to come to power. After the collapse of both the Social Democrats and the Communist International in Germany, Trotsky declared the Comintern incapable of drawing the necessary lessons from the historical catastrophe and called for the creation of a new world revolutionary organization. Rivera's allegiance to Trotskyism appears to be based on Trotsky's analysis of the German events and conclusions regarding the failure of the Comintern, in conjunction with the Trotskyist advocacy of artistic independence, despite Trotsky's personal doubts about the possibilities of a "proletarian art" in bourgeois society.

The Lovestone group was not prepared to draw the same conclusions as the Trotskyists, though they also opposed Stalin's theory of "social fascism." The primary cause for their break with Stalin in 1929 was the desire for an American leadership independent of Moscow, which, they argued, could not understand specific American conditions of backwardness regarding socialist tradition and native radicalism. The Lovestoneites centered their program on the United States and believed America was entering its "Victorian" period. They were denounced by Moscow as American Exceptionalists.

On 30 September 1933, the Militant headlined "For a New Party and a New International!" and generated discussions of the call for a new International on the left. In March 1934, a debate took place before a large audience of fifteen hundred between the leader of the Trotskyist Left Opposition, James Cannon, 
and the leader of the Right Opposition, Jay Lovestone. ${ }^{53}$ Lovestone argued for reform of the Third International and readmission of both the Lovestoneites and the international Trotskyists. Cannon denounced the miserable capitulation of the Stalinists to Hitler and argued that too many crimes and betrayals had taken place and that a clean banner was needed. The Trotskyists carried the day and attracted many independent radicals and disaffected members of the Communist Party who were wavering between the Lovestoneites and Trotskyists as leftist alternatives. Many joined the Left Opposition, leading to a surge of growth in the Trotskyist movement. ${ }^{54}$

\section{NEW WORKERS SCHOOL}

In this atmosphere of simmering debate over the united-front tactic and revolutionary regrouping into a new International in late 1933, Rivera painted the moveable mural "Proletarian Unity" as the culminating panel in his history of America at the New Workers School, financed with his Rockefeller money. He may have chosen the New Workers School because of his old ties with Bertram Wolfe, who helped him work out a complex iconographic program while allowing him complete artistic independence. Due to Rivera's fame, his talks at the school drew overflowing crowds and helped swell the size of the school's registration. Rivera commented that though he was a Trotskyist, he worked at the school in the spirit of "Communist unity." Communist unity at this moment in history necessarily referred to a united fight against fascism. The conflicting currents in radical politics were all represented in his "Proletarian Unity" panel, organized around the central figure of Lenin, whose large portrait dominates the composition. As in the RCA mural, Lenin joins together the hands of American workers, black and white, with a farmer and soldier. He is flanked by Marx and Engels on either side, and next to them the three main tendencies in the Soviet Union are represented by their leaders. In the upper left is a portrait of Stalin, evasively looking away from the viewer, and below him, Bukharin, the model for the Lovestone opposition, looking impish in comparison to the sinister Stalin, but also casting his gaze away from the viewer in the same direction as Stalin. In the upper right, and larger in size than both Stalin and Bukharin, Trotsky's gaze is direct and steadfast as he raises his fist in the symbolic gesture of revolutionary commitment. Just below Lenin are Rosa Luxembourg and Clara Zetkin. ${ }^{56}$ The leadership of the American factions is ranged along the bottom of the panel with William Z. Foster, Chair of the CPUSA below Bukharin, again evading the gaze of the viewer; Jay Lovestone of the Communist Party Opposition is next to him, followed by James Cannon of the Trotskyist Communist League. Labour leader Charles E. Ruthenberg, first 
General Secretary of the American Party, stands to the right of Cannon and next to him is Bertram Wolfe as "the teacher of the workers," pointing to the hands in unified embrace and symbolizing the message of the mural - proletarian unity. Beneath the clasped hands a scroll is held by Cannon and Ruthenberg inscribed with Marx's famous dictum: "Workers of the World Unite."

Trotsky's key association with Lenin is reinforced in the ninth panel of the series entitled "World War," in which the two Bolshevik leaders are pictured together leading the Russian Revolution. The banner of the Third International, created to replace the discredited Second International which capitulated to the German war drive in 1914, waves behind them. The carnage and grim profits of the First World War are represented by Woodrow Wilson and capitalist profiteers. In the lower left corner, opposite Lenin and Trotsky, is John D. Rockefeller, Jr. Two panels to either side of the Lenin panel show fascism as represented by Hitler and Mussolini, and between these panels and the Lenin panel are two smaller ones that represent the forces of resistance against fascism. In one, two workers strangle the Prussian eagle; in the other a worker holds back a hand wielding a fascist dagger. These efforts culminate in "Proletarian Unity," representing the unity of the working class "against the rising wave of fascist barbarism." 57 Siqueiros attacked the history of America murals on the grounds of factional prejudice, charging Rivera with being "the painter of the Trotzky-Lovestone [sic] coalition" which "attacked the Communist Party," and, of course, on the grounds of being insufficiently revolutionary. ${ }^{58}$

\section{THE RECREATED MURAL IN MEXICO CITY}

On 10 February 1934, when arrangements to transfer the RCA mural to the Museum of Modern Art had seemingly been all but concluded, the decision was made to destroy the murals and they were chopped off the walls. ${ }^{59}$ With the abortion of the RCA project and his dismissal, Rivera had been blacklisted and his commissions for murals in the United States canceled. ${ }^{60}$ His efforts to maintain artistic independence and a sense of revolutionary integrity while economically dependent on capitalist employers had become an impossible contradiction. At the same time, his efforts to win the approval of the Communist Party for his revolutionary art, while maintaining political independence from them, had also failed.

Rivera recreated the RCA mural in the Palace of Fine Arts in Mexico City, in a much smaller version, with all three sections on a flat wall in a manner resembling a triptych. Because it was now in a vastly different architectural and cultural environment where it did not have the impact it had in New York, most 
historians have interpreted the recreated version as Rivera's "artistic revenge" against the Rockefellers, and have regarded it as something of a museum piece whose political significance has been lost or subordinated to personal pique. This view is reinforced by reference to the added portrait of John D. Rockefeller, Jr. in the nightclub scene, near to the venereal microbes, which is widely regarded as the most important change made in the mural. ${ }^{61}$ Rivera, surely, took a measure of satisfaction in this particular variation from the original, but the significance of the additional political portraits and Communist banner in the right wing of the mural cannot be overlooked. The small group of Mexican Trotskyists which already existed was under attack by the Mexican police. ${ }^{62}$ In this context Mexico City was hardly a "safe" locale for this new version of the mural, whose alterations in the right wing publicly identified Rivera with Trotskyism.

Trotsky is centrally placed behind a red banner inscribed "Workers of the World Unite in the IV International," written in English, Spanish and Russian. Black and white workers on either side of Trotsky, together with Marx and Engels on the right, hold the banner aloft; the continuity of Trotskyism with the heritage of Marxism is thus also upheld. Jay Lovestone appears to the left of the banner, perhaps indicating Rivera's continued hope for the rapprochement of the Lovestoneites with the Trotskyists. Bertram Wolfe, in his familiar role as teacher, appears at the far right pointing to the founders of Marxism who symbolically lend their support to the Fourth International - thus symbolizing the new meaning of the mural. At the same time Rivera subtly acknowledges the distinction between his own political position and that of Wolfe, who does not point directly to Trotsky, but to his forebears. The decapitated idol sits behind the workers' leaders, its swastika covered with bullet holes, and the workers sit on the idol's head in symbolic triumph over Nazism.

Beginning with the RCA mural, Rivera grew increasingly trenchant in the assertion of his artistic and political independence, implicitly critiquing the Communist Party, while at the same time striving for their recognition and approval. In the context of a divided working class movement in Germany threatened by Hitler, and in the United States, threatened by severe economic crisis, Rivera took the very portion of his RCA mural which had come under heaviest attack by the bourgeoisie and enlarged it both physically and iconographically in the "Proletarian Unity" panel at the New Workers School in order to prove his revolutionary ardour, and as a plea for united antifascist mobilization. With Stalinism's critical failure to conduct such a fight, and Hitler's decisive triumph, Rivera shifted from an implicit critique of the Communist Party to a public avowal of the Trotskyist program, which codified 
its condemnation of this failure with the formal founding of the Fourth International in 1938. The new mural in Mexico City, entitled Man, Controller of the Universe, goes beyond the historical counterposition of capitalism and Communism in the RCA prototype to a sharpened commentary on the contemporary struggle between the forces of reaction and progress within Communism itself.

Bertram Wolfe's attempt to depoliticize Rivera's art in his 1963 biography is particularly ironic given the key role assigned to him by Rivera in the New Workers School and Mexico City murals as the "teacher" who points out to the viewer the significance of the political message in the artwork. Despite the attempts to discredit Rivera's engagement with radical politics, in particular his sympathy for Trotskyism for over a decade, a careful examination reveals Rivera to be more politically complicated than has been generally recognized, with his ideological evolution integral to the development of his complex imagery.

' For an insightful study of capitalist patrons, see Robert Linsley, "Utopia Will Not Be Televised: Rivera at Rockefeller Center," Oxford Art Journal 17:2 (1994), 48-62.

${ }^{2}$ See Diego Rivera and Bertram Wolfe, Portrait of America (Covici-Friede 1934). Also see Bertram D. Wolfe, The Fabulous Life of Diego Rivera (New York 1963), a revised and expanded version of his earlier biography, Diego Rivera: His Life and Times (New York 1939).

${ }^{3}$ Wolfe, Fabulous Life, 338.

${ }^{4}$ See especially Wolfe's last chapter in Fabulous Life, "Notes for a Future Biographer." ${ }^{5}$ The Latin American writer Octavio Paz was the first to question the expurgation and falsification of Rivera's political career for the purposes of "canonization and mummification." See Octavio Paz, "Social Realism in Mexico: The Murals of Rivera, Orozco and Siqueiros," Artscanada (December-January 1979-80), 56-65. Also see the critical review of the 1986 catalog Diego Rivera, A Retrospective by Oriana Baddeley, "Rivera Revived," Art History 11 (June 1988), 271-75.

${ }^{6}$ See, for example, Desmond Rochfort, The Murals of Diego Rivera (London 1987).

${ }^{7}$ Max Kozloff, "The Rivera Frescoes of Modern Industry at the Detroit Institute of the Arts: Proletarian Art under Capitalist Patronage," in Henry A. Millon and Linda Nochlin, eds., Art and Architecture in the Service of Politics (Cambridge, Mass. 1978), 216-229.

${ }^{8}$ See Alicia Azuela, "Rivera and the Concept of Proletarian Art," 125-130, and Ida Rodriquez-Prampolini, "Rivera's Concept of History," 131-138, in Diego Rivera: A Retrospective (Detroit 1986).

${ }^{9}$ Laurance Hurlburt, The Mexican Muralists in the United States (Albuquerque 1987), and Irene Herner de Larrea, Diego Rivera's Mural at Rockefeller Center (Mexico City 1990). Also cf. David Craven, Diego Rivera as Epic Modernist (New York 1997), which describes the second version of the mural in Mexico but does not compare it to the first version. 
${ }^{10}$ See Diego Rivera, "The Revolutionary Spirit in Modern Art," in The Modern Quarterly (Monthly) 4:3 (Autumn 1932), 51-57, reprinted in David Shapiro,ed., Social Realism: Art as a Weapon (New York 1980). The Modern Quarterly/Modern Monthly also printed open letters from Trotsky in March 1933, as well as articles by Trotskyist sympathizers such as Max Eastman and Sidney Hook. Also see Diego Rivera and André Breton [and Leon Trotsky], "Manifesto: Toward a Free Revolutionary Art," in Partisan Review 6:1 (Autumn 1938), 49-53, reprinted in Paul N. Siegel, ed., Leon Trotsky On Literature and Art (New York 1970). Trotsky co-authored the manifesto according to Isaac Deutscher, The Prophet Outcast, Trotsky: 1929-1940 (London and New York 1963), 431. Deutscher cites Trotsky's letter to Philip Rahv of 12 May and 30 July 1938, and James Burnham's letter to Trotsky, 12 April 1938, in The Archives.

"Trotsky referred to one such article: "We published in no. 3 of our review an article by Diego Rivera which dealt with a programmatic letter written by Haya de la Torre." A footnote cites the article as "Policy of Adaptation or Struggle Against American Imperialism," Clave (December 1938). The article was reprinted in the February 1939 issue of The New International under the title, "Haya de La Torre and Democracy." See Leon Trotsky, "Ignorance Is Not a Revolutionary Instrument," in Writings of Leon Trotsky: 1938-39 (New York 1969), 96.

${ }^{12}$ This later phase is documented in Rivera's autobiography written with Gladys March, and published after Rivera's death in 1957. March comments in the foreword: "There were aspects of his life which Rivera did not care to recall. ... The artist's account of his relations with Leon Trotsky, for instance, all but conceals a genuine attraction he felt toward Trotsky's Fourth International. But when I met Rivera, in 1944, he was seeking readmittance into the Communist Party." Diego Rivera and Gladys March, My Art, My Life: An Autobiography with Gladys March (New York 1960), 13.

${ }^{13}$ According to Wolfe, Rivera also excluded a photograph of his "Proletarian Unity" panel, which depicted both Stalin and Trotsky, for a monograph on his fifty-year retrospective in Mexico City in 1949 (published in 1952) because of his quest for readmission to the Communist Party. See Wolfe, Fabulous Life, 336. Rivera finally rejoined the $\mathrm{CP}$ in 1954.

${ }^{14}$ On the hidden hammer and sickle, see Lucienne Bloch, "On Location with Diego Rivera," Art in America 74 (Feb. 1986), 102-121.

${ }^{15}$ Letters from Lucienne Bloch Dimitroff to Laurance Hurlburt, 3 and 15 July 1982, cited in Hurlburt, 163.

${ }^{16}$ Diego Rivera, "The Stormy Petrel of American Art: Diego Rivera on His Art," The Studio 106 (July-December 1933), 24-25.

${ }^{17}$ Letter from Lucienne Bloch Dimitroff to Laurance Hurlburt, 3 July 1982, cited in Hurlburt, 163.

${ }^{18}$ Ben Shahn, from "A Profile of Ben Shahn" segment of The Open Mind (NBC-TV), 17 January 1965, 24, manuscript in the Museum of Modern Art Library, cited in Hurlburt, 162.

${ }^{19}$ Robert Evans [Joseph Freeman], "Painting and Politics: The Case of Diego Rivera," New Masses (February 1932). Freeman's first wife, the muralist Ione Robinson, had been one of Rivera's assistants in Mexico in 1929 when she first met Joseph Freeman, who was the Latin American correspondent for TASS, the Soviet news agency. Robinson comments on Freeman's hostility toward Rivera, which was based on, among other things, Freeman's suspicion of Rivera's Trotskyist sympathies, as well as the 
Diego Rivera and the Left

"bourgeois" content of his art. See Ione Robinson, A Wall to Paint On (New York 1946), 115-117.

${ }^{20}$ Joseph Lilly, "Rivera Perpetuates Scenes of Communist Activity for R.C.A. Walls and Rockefeller, Jr., Foots Bill," World-Telegram, 24 April 1933.

${ }^{21}$ Nelson Rockefeller's letter of 4 May 1933, from copy in Rockefeller Center Archives, cited in Hurlburt, 169.

${ }^{22}$ Lucienne Bloch Dimitroff letter to Laurance Hurlburt, 3 July 1982, cited in Hurlburt, 169.

${ }^{23}$ Rivera's wife, Frida Kahlo, who was with him during their nine months in New York, also supported and defended her husband. I might note here that the stormy relationship between Rivera and Kahlo, particularly his notorious philandering, have become the subject of much feminist analysis; while supporting, in general, the contributions of feminist analyses of gender, and despite Frida's later "affair" with Trotsky, I do not find it useful for the subject under discussion here, i.e. Rivera's relationship to left party politics leading up to the events of his controversial RCA mural and its altered recreation in Mexico, which occurred well before Trotsky's arrival in Mexico.

${ }^{24}$ See B.J. Field [Max Gould], "Broad United Front to Preserve Rivera Murals," Militant, 20 May 1933.

25 "Rivera Ousted For Mural," Workers Age, 15 May 1933.

${ }^{26}$ Robert Minor, "Rockefeller, Hitler Against Worker, Soldier and Negro," Daily Worker, 11 May 1933, emphasis in original. Minor went so far as to suggest that Rivera had painted the scene Rockefeller found so objectionable because "there was nothing else to paint" except "the cadaver of his old love and hate."

${ }^{27}$ Quoted in Workers Age, Supplement on Diego Rivera, 15 June 1933.

28 “Rockefeller Vandals Threaten Rivera Frescoes," Militant, 13 May 1933.

${ }^{29}$ B.J. Field [Max Gould], "Broad United Front to Preserve Rivera Murals," Militant, 30 May 1933; see also Rivera's reference to his association with Trotsky in "Rivera Says His Art is Red Propaganda," New York Times, 14 May 1933.

${ }^{30}$ Florence Arquin, Diego Rivera: The Shaping of an Artist 1889-1921 (Norman, Ok. 1971), 63-83; see also Diego Rivera, "What is Art For?" Modern Monthly 3:5 (June 1933), 75-278; and Wolfe, 65-66. Rivera was brought into the circle of Russians by his companion of seven years, the Russian painter Angelina Beloff, and met Marievna Vorobiev, Jacques Lipschitz, Zadkine, Larionov, Gontcharova, Bakst, Diaghilev, Boris Savinkov, Aleksandr Archipenko, Ilya Ehrenburg and others.

${ }^{31}$ Detroit exh. cat., 53, citing Anita Brenner, Idols behind Altars (New York 1929).

32 Wolfe, Fabulous Life, 216, 229.

${ }^{33}$ In November 1927, Rivera witnessed Trotskyist street demonstrations in Moscow and the expulsion of the Left Opposition which "gravely disturbed him." See Deutscher, 358.

34 John Bowlt, ed. and trans., Russian Art of the Avant-Garde: Theory and Criticism 1902-1904 (New York 1976), 278. Stalin spent the morning, on the day he met with Rivera's delegation, in the cutting room of the State Cinema Offices, personally cutting out 900 meters of Eisenstein's film Ten Days that Shook the World, eliminating Trotsky, chairman of the Military Revolutionary Committee that directed the Russian uprising, and even episodes involving Lenin. Rivera would have surely known about this censorship of the filmmaker who was a co-founder of the October group. Pravda, 28 October 1962, cited in Wolfe, n.215. 


\section{Left History 6.1}

${ }^{35}$ Wolfe, Fabulous Life, 221. This bureaucratic handling by the Stalinists which prevented Rivera from carrying out his mural commission was later criticized by Trotsky. See Leon Trotsky, "Art and Politics: A Letter to the Editors," Partisan Review 5:3 (August-September 1938), 3-10.

${ }^{36}$ The Sixth Congress of the Comintern, at which Trotsky was again denounced as a counter-revolutionary, was concluded just prior to Rivera's arrival in Moscow. For an account of how the Left Opposition managed to slip Trotsky's critique of the Sixth Congress draft program past the bureaucratic censors and into the hands of international delegates, including those of James Cannon who founded the American Trotskyist party, see James P. Cannon, "The Beginning of the Left Opposition," The History of American Trotskyism (New York 1972).

${ }^{37}$ See Trotsky's critique, "The Draft Program of the Communist International - A Criticism of Fundamentals," in Leon Trotsky, The Third International After Lenin (New York 1970); see also Leon Trotsky, The Revolution Betrayed (New York [1937] 1972). ${ }^{38}$ Rochfort, 64-65.

${ }^{39}$ Diego Rivera, "Position of the Artist in Russia Today," Arts Weekly, (March 1932), 67, quoted in Wolfe, Fabulous Life, 224.

${ }^{40}$ The quarrel was over Rivera's Stalinophobic attack on Cárdenas and support to his rival, Almazán, a right-wing general. Since Trotsky was publicly closely associated with Rivera, he felt nothing short of a public breach could free him of responsibility for Rivera's political position. See Deutscher, 444; also Antonio Rodriguez, A History of Mexican Mural Painting (New York 1969), 271, 499 n.69. For Rivera's version of the break with Trotsky, ascribed to personal differences due to an unspecified "misunderstanding," see "Trotsky and Rivera Split Over Revolution; Exile Quits Artist's Home in Mexico City," 13 April 1939, and "Rivera Still Admires Trotsky; Regrets their Views Clashed," 15 April 1939, New York Times. On Rivera's Stalinophobia at this time see "Says Stalin Seeks Hold Over Mexico," 29 October 1939, New York Times. Rivera was most likely reacting to the Stalin-Hitler pact.

${ }^{41}$ Wolfe, Fabulous Life, 233.

${ }^{42}$ David Alfaro Siqueiros, "Rivera's Counter-Revolutionary Road," New Masses, 29 May 1934. Rivera was also denounced as a renegade and read out of the community of revolutionary artists at the Soviet Kharkov conference in 1930. One of the reasons given, among others, was flirting with Trotskyism. See Harvey Klehr, The Heyday of American Communism: The Depression Decade (New York 1984), 75.

${ }^{43}$ Wolfe, Fabulous Life, 233-34.

${ }^{44}$ For a detailed version of these events from the perspective of the American CP, see Evans [Freeman], "Painting and Politics"; also Siqueiros, "Rivera's CounterRevolutionary Road."

${ }^{45}$ Evans [Freeman], "Painting and Politics."

${ }^{46}$ Ibid.

${ }^{47}$ See Ernest Gruening, “Mexico's Native Master of Mural Art: The Prolific Brush of Diego Rivera Vividly Depicts the History, Life, Toil and Aspirations of His People," New York Times, 21 April 1929.

${ }^{48}$ Francis Flynn Paine, Diego Rivera, exhibit catalogue (New York 1931), 33, 35; Paine also convinced the Rockefellers to set up the Mexican Arts Association in 1930, whose board included wealthy gallery owners, in order to take advantage of the more open relations between Mexico and the U.S. 
49 Rivera, "The Revolutionary Spirit in Modern Art," 57.

${ }^{50}$ Diego Rivera, "What is Art For?” Modern Monthly 3:5 (June 1933), 275-278.

${ }^{51}$ See Leon Trotsky, Literature and Revolution (Ann Arbor 1960), written 1923; Paul N. Siegel, ed., Leon Trotsky on Literature and Art (New York 1970); Alan M. Wald, The New York Intellectuals: The Rise and Decline of the Anti-Stalinist Left from the 1930s to the 1980s (Chapel Hill, N.C. 1987).

${ }^{52}$ See Albert Halper, Good-Bye, Union Square: A Writer's Memoir of the Thirties (Chicago 1970). Apparently, Rivera was mainly heckled by William Dunne, editor of the Daily Worker.

${ }^{53}$ The debate took place on 5 March 1933. See "Big Crowd at Debate," Militant, 10 March 1934; Workers'Age did not comment.

${ }^{54}$ Cannon, 136-137.

${ }^{55}$ Hurlburt, 176, citing address by Rivera on the occasion of Jay Lovestone's departure for a trip to Europe, n.d., Wolfe Collection, Hoover Institute.

${ }^{56}$ The acknowledgment of female leadership here may have been inspired not only directly by the powerful roles played in Germany by Luxemburg and Zetkin, but by Rivera's recognition of the predominance of women from the International Ladies' Garment Workers Union in the membership of the Lovestone group and New Workers School.

${ }^{57}$ Rivera, Portrait of America, 231.

${ }^{58}$ Siqueiros, "Rivera's Counter-Revolutionary Road"; for a discussion of bourgeois and leftist reactions, and a defense of Rivera, see Bertram D. Wolfe, "Diego Rivera on Trial," The Modern Monthly (July 1934), 337-341; also see Thomas Craven, Modern Art: The Men, the Movements, the Meanings (New York 1934).

${ }^{59}$ For a detailed account of these events, see Hurlburt; for a very different account see an abridged article based on a lecture given by Nelson Rockefeller, New York Times Magazine, 9 April 1967.

${ }^{60}$ Albert Kahn, for example, sent a cable to Rivera revoking a General Motors commission for the Chicago World's Fair. See Hurlburt, 173.

${ }^{61}$ This includes the view of Bertram Wolfe. In his 1939 biography, Diego Rivera: His Life and Times, 375, Wolfe comments: "there being some extra space to fill, he [Rivera] added a few additional figures, among them Trotsky and Marx. ... But the most interesting change from the Rockefeller Center original was one not required by the architecture: the introduction into the night-club scene ... of John D. Rockefeller Jr." Wolfe never quite explains why the architecture required the introduction of Trotsky and the banner of the Fourth International.

${ }^{62}$ For accounts of the attacks against the Trotskyist movement in Mexico, see Militant articles: "Mexican Police Seize International Communists," 5 May 1934, and "Mexican Nazis Attack Trotsky," 16 June 1934. Trotsky was himself assassinated by a Stalinist agent in Mexico on 21 August 1940. 